The effect of family business professionalization on dividend payout Peer-reviewed author version

MICHIELS, Anneleen; Uhlaner, Lorraine \& DEKKER, Julie (2017) The effect of family business professionalization on dividend payout. In: Journal of small business and enterprise development, 24(4), p. 971-990.

DOI: 10.1108/JSBED-01-2017-0023

Handle: http://hdl.handle.net/1942/24259 


\title{
The effect of family business professionalization on dividend payout
}

\author{
Michiels, A., Uhlaner, L., Dekker, J. \\ Journal of Small Business and Enterprise Development (2017)
}

\begin{abstract}
This paper contributes to our understanding of dividend payout in privately held familycontrolled firms by adopting a family business professionalization perspective. Based on a sample of 492 small to medium-sized family-controlled firms, the results show that professionalized family firms pay higher dividends to their shareholders than less professionalized firms. In particular the use of financial control systems, nonfamily involvement in governance systems, and the use of human resource control systems have a positive significant impact on the average level of dividend payout.
\end{abstract}

\section{INTRODUCTION}

The topic of dividend policies in private family firms has aroused the interest of corporate finance and governance scholars and practitioners alike. However, many questions concerning the dividends in privately held family firms remain unanswered. While past research has investigated the influence of family ownership and/or management on dividend policies (e.g. Chen et al., 2005; Farinha, 2003; Gugler, 2003; Huang et al., 2012; Pindado et al., 2011; Setia-Atmaja et al., 2009; Setia-Atmaja, 2010; Yoshikawa and Rasheed, 2010), it typically focuses on listed family firms and ignores the much larger and more diverse group of privately held family-owned and managed firms. Studying the dividend behavior of this heterogeneous group of firms may be very interesting, since these types of firms are assumed to follow a logic that is driven by both economic and non-economic motives (Gallo et al., 2004; Gómez-Mejía et al., 2007; Koropp et al., 2014). The desire to maintain family control may influence decisionmaking in private family firms, specifically financial decisions such as dividend payouts (Blanco-Mazagatos et al., 2007; Gallo et al., 2004; Romano et al., 2000). For example, private family firms often postpone growth-promising investment opportunities rather than issue external equity, to avoid the possible threat of weakened family control (Koropp et al., 2014; 
Mahérault, 2000; Wu et al., 2007). So agency costs, for example due to altruism, nepotism or self-control problems within the controlling family, may influence financial decisions in family firms.

A recent stream of literature has started to open the black box of dividend payments in privately held family firms, investigating the effect of family influence in ownership and management (González et al., 2014; Vandemaele and Vancauteren, 2015) and the use of family governance practices (Michiels et al., 2015) on a firm's dividend policy. However, our understanding of other antecedents of dividend payouts is still quite limited. We address this by examining the effects of family firm professionalization. Since some of the determinants of dividend payout level found in earlier studies (for instance, generational stage or the presence of a non-family CEO) (González et al., 2014; Vandemaele and Vancauteren, 2015) are in fact aspects of professionalization in a family firm, the aim of the present study is to target family business professionalization in a more holistic manner.

More specifically, as professionalization helps deal with the conflicts of interest that emerge at family level, we expect dividends to be an outcome of professionalization. In other words, we expect firms with a higher degree of professionalization to have higher dividend payouts. Recent academic work has broadened the professionalization concept beyond the sole presence of a non-family CEO towards a more multidimensional understanding of its content. Authors such as Hall and Nordqvist (2008), Stewart and Hitt (2012), and Dekker et al. (2013) have pointed to the importance of formal governance systems, board activeness, and formal control systems as important pieces of the professionalization puzzle. We adopt this family business professionalization perspective, as it not only encompasses increased non-family involvement in management and governance, but also these other aspects.

We test our hypotheses using a sample of 492 small to medium-sized Belgian family firms ${ }^{1}$. The results suggest that professionalized family firms pay higher dividends to their shareholders than less professionalized family firms. More specifically, the results support our hypothesis that the use of formal financial and human resource control systems may lessen or prevent agency problems related to altruism or nepotism, as seen by their significant positive impact on the average dividend payout. Next, our findings show that dividends are an outcome of effective governance systems (in this case: non-family involvement in governance systems) rather than a substitute, which is in line with the results of La Porta et al. (2000)).

\footnotetext{
${ }^{1}$ By family firms, we are in this paper referring to firms where the majority ownership is held by one family (i.e. family-controlled firms)
} 
This study makes a number of contributions to the academic literature. First, while professionalization research emanates mainly from the management literature, and dividend research from the corporate finance literature, we integrate insights from both disciplines advancing both streams of literature. In particular, as our results indicate that professionalized family firms pay higher dividends, we add an important management variable which future finance research should take into account when examining payout policies. Second, while prior research on dividend payouts compares publicly held family and non-family firms (e.g. Chen et al., 2005; Farinha, 2003; Gugler, 2003; Setia-Atamaja et al., 2009), we investigate differences in dividend payout within the group of privately held family firms. More specifically, our paper provides an extended understanding of dividend policy that takes into account different types of private family businesses, thereby answering recent calls for researchers to go beyond comparisons between family and non-family firms and focus on the heterogeneous nature of family firms (Chua et al., 2012; Nordqvist et al., 2014) and on the financial consequences of private family ownership (Carney et al., 2013). Third, by adopting a broader family business professionalization perspective, we contribute to the family business literature as our reasoning goes beyond the effect of family involvement on dividend payout alone, as was investigated by González et al. (2014). As a successful application of a more extended operationalization of professionalization, this study should also provide guidance on this topic for entrepreneurship researchers more generally. Fourth, it may be of interest to family business consultants and (potential) investors, as the results clarify the conditions in which family-controlled firms have a high or low dividend payout policy. Finally, the findings enhance our understanding of the varying preconditions for dividend policy, such as the objectives of patient (financial) capital and the reinvestment of equity to achieve business growth. Investigating dividend payout in the context of components other than family ownership (in this case, professionalization) can therefore broaden our understanding of dividend payout.

This paper is structured as follows. In the next section, we present a brief overview of the theoretical and empirical literature on professionalization and dividend payout in familycontrolled firms and subsequently develop hypotheses. Next, we explain our methodology and present the empirical results. Finally, we conclude with a discussion of the results and their implications for both researchers and practitioners.

\section{LITERATURE REVIEW AND HYPOTHESES DEVELOPMENT}

\subsection{The importance of dividend payouts in family-controlled firms}


Family-controlled private companies often use dividend payouts as a tool to enhance internal business financing, i.e. to keep family investors happy. Such firms prefer internal business financing as opposed to relying on external equity, as it enables them to maintain tight control and keep decision-making within the owning family so as to preserve the firm's socioemotional wealth (Blanco-Mazagatos et al., 2007; Gallo et al., 2004; Gómez-Mejía et al., 2007). The desire to retain control stems from the will to preserve the power to exercise authority and shape strategy in one's own business, which is a very common characteristic of family businesses (Gedajlovic et al., 2004; Gersick et al., 1997; Yildirim-Öktem and Üsdiken, 2010).

Different forces may influence dividend payouts in privately held family-controlled firms. On the one hand, some argue that privately held firms are more likely than publicly held firms to retain earnings (leading to a reduced dividend payout) in order to avoid external funding (Carney and Gedajlovic, 2002; Poutziouris, 2001). By retaining earnings, the firm has more resources for reinvestment in improvements without resorting to external funding (whether with loans or equity). This will result in a lower dividend payout. Furthermore, due to highly concentrated ownership, the agency problems associated with free cash flow between majority and minority shareholders are traditionally considerably lower, thereby reducing the likelihood of dividend payments (Easterbrook, 1984; Jensen, 1986; Rozeff, 1982).

On the other hand, a more recent stream of literature argues that concentrated family ownership and owner-management is associated with substantial agency costs which are caused by altruism and self-control problems (Lubatkin et al., 2005; Schulze et al., 2003; Schulze et $a l ., 2001)$. When investigating dividend policy in light of these agency costs, researchers find that paying out dividends can be a way to alleviate agency problems between family and minority shareholders (Pindado et al., 2011) and between active and passive family shareholders (Michiels et al., 2015).

\subsection{The professionalization construct}

Firm professionalization is generally understood in an organizational development context. As a firm evolves from a start-up through the growth and maturity life cycle phases, the complexity of its operations increases, as well as the necessity for more sophisticated management, governance and control systems. It therefore needs to professionalize in order to advance to the next level (Dekker et al., 2013; Flamholtz and Randle, 2007; Gabrielsson, 2007; Gedajlovic et al., 2004; Whisler, 1988). 
To identify and explain the differences in the level of dividend payout in private family businesses, we adopt a family business professionalization perspective. The modern interpretation of this construct is that it not only encompasses the level of non-family involvement in management, but also other important related aspects such as formal control systems, governance systems, and board activity, which can, individually or combined, affect dividend payout. Recent researchers have demonstrated the importance of approaching family business professionalization as a multidimensional construct (Dekker et al., 2013; Hall and Nordqvist, 2008; Songini, 2006; Stewart and Hitt, 2012). Based on their extensive review of key studies, Hall and Nordqvist (2008) and Dekker et al. (2013) assert that the extant research on professionalization, especially in family businesses, tends to equate professionalization with the presence or absence of an external, non-family manager (e.g. Berenbeim, 1990; Bloom and Van Reenen, 2007; Daily and Dollinger, 1992; Gulbrandsen, 2005; Fletcher, 2002). In other words, family business researchers tend to operationalize the professionalization concept as a binary variable, lacking depth and providing an oversimplified representation of reality. Songini (2006) stresses the importance of going beyond this single item, also including such variables as the presence of formal governance mechanisms, and formal strategic planning and control systems. Dekker et al. (2013) developed an even broader conceptualization and operationalization of the professionalization construct, including additional dimensions such as formal training, meritocratic values, formalized structures, and use of independent directors (Stewart and Hitt, 2012).

For the present research, we adopt the five dimensions proposed by Dekker et al. (2013) as aspects of professionalization, including financial control systems, human resource control systems, non-family involvement in governance systems, top level activeness, and decentralization of authority. We elaborate further on the importance of each of these dimensions as aspects of professionalization in the following section.

\subsection{Hypotheses and rationale}

\section{Professionalization of control systems and dividend payout}

One way to examine family firm professionalization is by looking at the level of formal control systems present in the business. We distinguish between financial controls, such as budget systems, planning systems and firm performance evaluation systems, and human resource control systems which are more people-related, like formal recruitment, training, personnel evaluation, and reward systems. 
First, numerous authors consider finance-related control systems as an aspect of professionalization (Daily and Dollinger, 1992; Flamholtz and Randle, 2007; Giovannoni et al., 2011; García Pérez de Lema and Duréndez, 2007; Samuelsson et al., 2016; Songini, 2006). Formal financial control systems, such as the use of formal budgets or the existence of a budget evaluation system, reduce the likelihood that corporate insiders will secretly divert assets for personal use or use corporate resources for unprofitable projects (La Porta et al., 2000) at the expense of other owners. Thus, we contend that an increased level of formal financial control makes it more difficult for corporate insiders to benefit privately. This, in turn, might lead to greater retained earnings and thus more funds available for payouts. The presence of formal financial controls is thus likely to be associated with increasing dividend payouts. We therefore hypothesize that:

Hla. Formalization of finance control systems leads to a higher dividend payout in family firms.

Besides financial control systems, people-related control systems also appear to be an important aspect when professionalizing a business, especially in the family business context (De Kok et al., 2006; Dyer, 2006; Kopriva and Bernik, 2009; Kotey and Folker, 2007; Reid et $a l .$, 2002). Previous research has found the use of these human resource practices to vary widely among small (family) firms (De Kok and Uhlaner, 2001; Michiels, 2017), and their adoption has been found to positively affect firm performance (Dekker et al., 2015). Problems relating to parental altruism or nepotism are not uncommon in the family business context (Kellermanns and Eddleston, 2004). Using formal human resource control systems might lessen or prevent these problems.

More specifically, the use of formal human resource control systems can reduce the likelihood that excessive salaries or exorbitant perquisites will be offered to family members due to altruism or nepotism. Formal control systems such as non-personalized evaluation and incentive pay will discourage managers from investing in low return showcase projects or providing unjust payment to family members (Ward, 1997; Chua et al., 2009; Michiels et al., 2013). The implementation of these controls will therefore likely result in higher retained earnings and, again, more funds available for dividend payouts. The presence of formal HR controls is thus likely to be associated with increasing dividend payout. We therefore hypothesize that:

H1b. Formalization of HR control systems leads to a higher dividend payout in family firms. 


\section{Professionalization of top-level functions and dividend payout}

The three remaining dimensions of family firm professionalization relate to a shift in decision-making away from the CEO and core family members and toward the inclusion of (more) non-family members on the board of directors and the top management team, a more active board of directors and management team, and greater decentralization or delegation of authority.

First, the degree of professionalization of the board of directors and the management team reflects the extent to which family businesses have opened up their governance bodies to non-family members. It encompasses the presence of non-family board members, independent board members, non-family managers, and even a non-family CEO, all of which are typically related to the overall level of professionalization of family businesses (Dekker et al., 2013; Songini, 2006; Stewart and Hitt, 2012) and has been found to positively impact firm performance (Dekker et al., 2015). Non-family managers and board members can bring relevant expertise into the company (García Pérez de Lema \& Duréndez, 2007) and can also reduce some of the agency hazards due to familial altruism and self-control issues among family firm owners (Carney, 2005; Dyer, 1989; Sciascia and Mazzola, 2008). The same holds for nonfamily and independent directors, who can increase the effectiveness of the monitoring function of the board of directors and bring more diverse perspectives and experiences to the board (Filatotchev et al., 2005). This way, they can prevent powerful insiders from holding excessive cash within the firm when a payout would be more appropriate. Based on the previous arguments, we hypothesize that:

H2a. Non-family involvement in governance systems leads to a higher dividend payout in family firms.

Professionalization of top-level functions can also be assessed through the concept of top-level activeness of both the board and management team, i.e. whether these groups meet on a regular basis and fulfill an 'active' role in advising and supervising the firm's activity (Dekker et al., 2013; Flamholtz and Randle, 2007; Lane et al., 2006). This contrasts with less professionalized family businesses in which a board is often only present to meet legal requirements, sometimes referred to as 'rubber stamp' boards (Pieper et al., 2008), and where the management team has no formal meetings. 
Dominant shareholders often pursue their private interests to the detriment of minority shareholders (Anderson and Reeb, 2004). When a business lacks an effective monitoring body, powerful insiders can hold excessive cash within the firm, allowing the family to freely exploit these resources for their private benefits (DeAngelo and DeAngelo, 2000). Increased board activeness can counteract such phenomena. A well-functioning board of directors can monitor and restrict opportunistic behavior within the controlling family (Anderson and Reeb, 2004). As research shows, the presence of an active board influences the quality of decision-making in family firms (Gersick et al., 1997; Ward, 1997), and thus also affects important financial decisions, such as the level of dividend payouts. For example, the board can increase dividend payout in order to reduce free cash flows that might otherwise be expropriated (La Porta et al., 2000).

We argue that as a family firm's board and management becomes more professionalized, they will also become increasingly aware of the fact that they can use a dividend policy to alleviate possible conflicts of interests between the shareholders of the firm. This way, they could see dividend payouts as a mechanism to reduce conflicts between minority and majority (Pindado et al., 2011) or active and passive (Michiels et al., 2015) shareholders. For these reasons, we propose the following hypothesis:

H2b. Top level activeness leads to a higher dividend payout in family firms.

Finally, the decentralization of authority is also often mentioned as an important indication of professionalization (Dyer, 1989; Flamholtz and Randle, 2007; Stewart and Hitt, 2012; Whisler, 1988). According to Daily and Dollinger (1992), failing to share and delegate power could even lead to the firm's demise. After all, when an entrepreneur is able to successfully delegate operational decisions, he or she can invest more time in making essential strategic or financial decisions, for example setting up a dividend policy. Therefore, we formulate our last hypothesis as follows:

H2c. Decentralization of authority leads to a higher dividend payout in family firms.

Figure 1 below shows the expected relationship between various dimensions of professionalization and dividend payout.

Insert Figure 1 about here 


\subsection{Sample and data collection}

The empirical data that is used to assess the effect of family business professionalization on dividend payout belongs to a wider survey exploring family business professionalization within the group of small and medium-sized enterprises located in Flanders, the northern part of Belgium. This data was gathered by means of an electronic questionnaire, which was emailed to all privately held SMEs with at least 10 employees in order to exclude micro-organizations. The population criteria led to a final selection of 6,556 firms, which were drawn from the BelFirst database, a financial database held by Bureau Van Dijk containing detailed financial information on all non-listed companies in Belgium. In 2010, we emailed the questionnaire to all the chief executives of the firms in the sample. After three waves of emails, we received a total of 890 completed questionnaires, corresponding to a response rate of 13.58 percent. Subsequently, to extract the family businesses from the response group, we applied the following definition of a family controlled firm: more than 50 percent of ordinary voting shares are owned by members of the largest single family group related by blood or marriage (Chrisman et al., 2004; Chua et al., 1999; Westhead and Howorth, 2007). This resulted in a final response group of 532 family controlled firms.

In order to assess our dependent variable, i.e. dividend payout, we used the Bel-First database to collect additional financial information on these 532 family-controlled firms for the three-year period (2010-2012) following questionnaire data collection. The information retrieved from the financial statements was merged with the existing dataset. After omitting the cases that reported missing values for the dividend payout, we obtained a final useable dataset of 492 private family-owned SMEs.

The dataset in this study combines both survey data and secondary data. Thus, as we measured the dependent and independent variables (and several of the control variables) using different instruments, the problem of possible common method bias is minimized. Also, to improve consistency in the responses, we targeted a single respondent (CEO). Further, in order to assess potential non-response bias, we tested for differences between early and late respondents, as the latter are more similar to non-respondents (Kanuk and Berenson, 1975; Oppenheim, 2000). T-tests revealed no significant differences between early and late respondents, or between the three different waves of reminders that were sent out. In addition, an insignificant F-value for Levene's test for equality of variances supports the conclusion of 
equal variance in the groups of early and late respondents. Based on this, we expect the chance of biased responses to be very small (Kanuk and Berenson, 1975).

\subsection{Measures}

This section lists the definitions of the dependent, independent, and control variables used in the present study. A summary is provided in Table 1 below.

Insert Table 1 about here

\section{Dependent variable}

Consistent with previous empirical research investigating dividend payouts (e.g. González et al., 2014; Lee, 2010; Lipson et al., 1998), we use a dividend ratio which is defined as the amount of dividend payout divided by total assets. This variable is averaged for three years (2010-2012).

\section{Independent variables}

We extracted all five dimensions of family firm professionalization from an exploratory factor analysis by Dekker et al. (2013). Their five-dimensional framework is based on an extensive literature review, encompassing multiple professionalization components, and converted into a numeric scale that assesses the level of professionalization for a family business per dimension. The five professionalization $(\mathrm{P})$ dimensions derived from the principal component analysis are: Financial Control Systems (P1, Cronbach's alpha: 0.78); Human Resource Control Systems (P2, Cronbach's alpha: 0.61); Non-family Involvement in Governance Systems (P3, Cronbach's alpha: 0.65); Top Level Activeness (P4, Cronbach's alpha: 0.55); and Decentralization of Authority (P5, Cronbach's alpha: 0.57). ${ }^{2}$ Although the Cronbach's alpha values for dimensions P4 and P5 are slightly below the general threshold value of 0.60 for exploratory factor analysis (Hair et al., 2006), it is argued that a value of 0.50 can be acceptable for social science data (Kline, 2013). The exact wording of these items, as well as measures of reliability and validity are included in the Appendix. All five dimensions are included in the Tobit regression model based on the derived standardized factor scores,

\footnotetext{
${ }^{2}$ For more detail concerning the development and validity of the five factors, see Dekker et al. (2013).
} 
which present how each company scores on the group of items with high loadings on a specific factor. We computed the factor scores for each of the five revealed professionalization dimensions, for each company in the data set. These factor scores then represent each company's scores on the group of items with high loadings on a factor. By using Barlett approach, we generated orthogonal factor scores with a mean of 0 and a standard deviation of 1.

\section{Control variables}

Consistent with prior research, we included several firm characteristics that might influence the dividend payout ratio. The analyses include the natural logarithm of firm age in 2010 as a proxy for a firm's maturity. Older firms are typically in later growth phases, which gives rise to excess cash, and are thus more likely to pay dividends (González et al., 2014; Sharma, 2011; Yoshikawa and Rasheed, 2010).

As larger firms tend to pay out higher dividends (Fama and French, 2001; Fenn and Liang, 2001; Sharma, 2011; González et al., 2014), the natural log of total assets, averaged over three years (2010-2012), is included as a proxy for firm size. Moreover, larger firms are found to be positively associated with professionalization (e.g. De Kok et al., 2006) and thus should be included as a control variable in this study.

Profitability has proven to be positively related with a firm's dividend payout ratio (e.g. González et al., 2014; DeAngelo et al., 2004; Fama and French, 2001; Sharma, 2011). Thus, we include the firm's return on assets, which is measured as income before interest, tax, depreciation and amortization, divided by total assets, averaged over three years (2010-2012).

The model controls for (long-term) leverage as higher debt means higher interest payments and, consequently, less remaining cash to pay out in the form of dividends (DeAngelo et al., 2004; González et al., 2014; Sharma, 2011). Additionally, banking covenants and restrictions imposed by debtholders can limit the firm's ability to pay out dividends (Jensen and Meckling, 1976; Baker, 1989; Farinha, 2003; Hu and Kumar, 2004). The variable leverage is calculated as long-term debt divided by total assets, averaged over three years (2010-2012).

According to the free cash flow hypothesis (Jensen, 1986), higher cash holdings should lead to higher dividend payouts (DeAngelo et al., 2006; Farinha, 2003). Thus, the model controls for a firm's ability to pay back its short-term liabilities (debt and payables) with its short-term assets (cash, inventory, receivables) with the variable liquidity, averaged over three years (2010-2012). 
Next, a firm's investment opportunities can be expected to negatively influence the level of dividend payouts because they give a strong incentive for the firm to retain cash (and thus not to pay out dividends). Consistent with prior research (Carney and Gedajlovic, 2002; Denis and Osobov, 2008; Fama and French, 2001; Michiels et al., 2015; Naceur et al., 2006), growth rate of assets in $2011\left(\mathrm{dA}_{\mathrm{t}} / \mathrm{A}_{\mathrm{t}}\right)$ is a proxy for a firm's investment opportunities, because greater growth indicates superior investment opportunities (DeAngelo et al., 2004).

The generational phase of a family firm might also influence the decision to pay dividends because agency problems are likely to differ between controlling-owner and next generation family firms (Lubatkin et al., 2005, Blanco-Mazagatos et al., 2007). We control for this possible influence by including a dummy variable which equals one for first-generation family firms, and zero for later generation family firms.

Consistent with many other studies on dividend payout (e.g. Carney and Gedajlovic, 2002; Farinha, 2003), we control for ownership dispersion and include the number of owners in 2010 .

Finally, we control for competitive environment since it dictates the profit potential of a business (Porter, 1980) and can in turn indirectly influence the ability to pay dividends. Four sector dummy variables are included (wholesale, construction, manufacturing and services).

\subsection{Data analysis}

Our sample includes many firms that paid no dividends during the years analyzed. More specifically, 69 percent of all firms did not pay out a dividend during the period 2010-2012. As our dependent variable (dividend payout) cannot have negative values, it has the special feature that it has two possible outcomes: (1) zero, when no dividends are paid, and (2) a positive value, when dividends are paid. In other words, our dependent variable is left censored at zero. As indicated by Wooldridge (2009), when the dependent variable is constrained and there is a clustering of observations at this constraint (in our case: non-negative and clustering at zero), estimates based on ordinary least squares regressions will be biased and inconsistent. The suggested solution at this point is to use a Probit or Tobit Model. We prefer to use a Tobit Model, because it does not throw away any information (Tobin, 1958). The Tobit Model supposes that there is an unobservable (latent) variable that linearly depends on the independent variables. It can thus be expressed by the following equation:

$$
y_{i}= \begin{cases}y_{i}^{*} & \text { if } y_{i}^{*}>0 \\ 0 & \text { if } y_{i}^{*} \leq 0\end{cases}
$$


Where $y_{i}^{*}$ is the latent variable $\left(y_{i}^{*}=\beta x_{i}+u_{i,} \sim N\left(0, \sigma^{2}\right)\right)$

The coefficients are interpreted as the combination of the change in $y_{i}$ of those above the zero limit, weighted by the probability of being above zero and (2) the change in the probability of being above zero, weighted by the expected value of $y_{i}$, if above zero (McDonald and Moffit, 1980).

\section{RESULTS}

\subsection{Descriptive statistics and univariate analyses}

Table 2 reports the descriptive statistics and correlations for all variables. The mean values and standard deviations for the five professionalization factors are not reported as they are standardized factor scores with a mean value of zero and a standard deviation of one. The mean (median) sample firm is about 27 (23) years old, employs 29 (19) people and is owned by 2.26 (2) owners. Sixty-one percent of all sample firms are second or later generation family firms. About 20\% of the sample firms pay out dividends (19.92\% in 2010; 20.73\% in 2011 and $20.33 \%$ in 2012). These percentages correspond to previous studies on Belgian private firms (Michiels et al., 2015; Rommens et al., 2012). About 31\% of the sample firms paid a dividend at least once during the period 2010-2012.

The dependent variable (Dividend payout) is significantly and positively correlated with $P 2$ (non-family involvement in governance systems), P3 (human resource control systems), and Profitability. The variable Leverage is significantly and negatively correlated with the dividend payout ratio. The highest absolute correlation between the explanatory variables is 0.34 (in absolute value), which is well below the 0.80 threshold above which multicollinearity problems could arise (Gujarati, 2003). Also, the variance inflation factor (VIF) values indicate no multicollinearity problems as the largest VIF of 1.54 is again considerably less than the 10 threshold (Gujarati, 2003).

Insert Table 2 about here

\subsection{The impact of family firm professionalization on dividend payout ratio}

In order to investigate the factors that influence the level of dividend payout in a family firm, we use a Tobit model (also called a censored regression model) in STATA. All regression results are based on heteroscedasticity-consistent standard errors. 
Insert Table 3 about here

As indicated in Table 3, three out of five professionalization dimensions have a positive significant influence on the level of dividend payout in private family firms. More specifically, the use of financial control systems, non-family involvement in governance systems, and the use of HR control systems lead to a higher dividend payout ratio. Thus, Hypotheses 1a, 1b and $2 \mathrm{a}$ are supported by our results. Neither decentralization of authority nor top-level activeness has a significant relationship with dividend payments. Although the signs of their coefficients are positive as expected, they are not statistically significant and thus we find no support for Hypotheses $2 \mathrm{~b}$ and $2 \mathrm{c}$ based on our analyses.

As far as the control variables are concerned, we find a significant positive effect of firm age and profitability. We thus find that older, more profitable family firms pay out higher dividends than younger or less profitable family firms, a result which is in line with previous payout studies. Firm leverage has a significant negative influence on the payout ratio, also similar to previous research (DeAngelo et al., 2004; González et al., 2014; Sharma, 2011). This confirms the suggestion that debt might be considered as an alternative mechanism to minimize potential free cash flow problems (Farinha, 2003; Renneboog and Trojanowski, 2007).

Next, similar to the findings of previous research, a firm's investment opportunities (proxied by growth rate of assets) significantly negatively affects dividend payout. Firm size, liquidity and the number of owners do not significantly influence the dividend payout ratio. In contrast to previous research (Vandemaele and Vancauteren, 2015), the variable generation has no significant effect on dividend payout.

Although some studies investigating family businesses exclude single-owner firms, we decided to keep these firms in our sample so as not to needlessly reduce the sample size. Additionally, the control variable Number of owners has no (univariate or multivariate) significant influence on dividend payout. As a robustness test, we performed the Tobit analyses with a reduced sample size, excluding 167 family firms with only one owner). As shown in Table 4, the results remain similar, which indicates that our results are robust for single-owned firms as well as family firms with multiple owners.

Insert Table 4 about here

\section{DISCUSSION}




\subsection{Discussion}

The results support our first three hypotheses: firms with advanced financial control systems (for example formalized financial goals and objectives), formalized human resource control systems (for example incentive pay), and non-family involvement in governance systems (on the board of directors and the management team) pay out higher dividends. Our results do not support the last two hypotheses since we find that neither decentralization of authority nor top-level activeness has a significant effect on dividend payout.

We posit that agency problems relating to parental altruism or nepotism are more likely when there are weaker control systems. Our results are consistent with this interpretation, given that we find that the use of formal (both financial and human resource) control systems in family firms results in higher dividend payouts. Furthermore, formal control systems may reduce agency costs related to parental altruism because they reduce the amount of cash available to use for excessive salary or perquisites for family members.

Next, as non-family involvement in governance systems positively influences dividend payout, our results provide additional support for the suggestion that non-family involvement in the firm can reduce some of the agency costs related to, for example, parental altruism or self-control problems (Carney, 2005; Dyer, 1989; Sciascia and Mazzola, 2008). After all, nonfamily involvement in the firm seems to reduce possible misuse of excess cash within the firm since more cash is paid out in the form of dividends. Our results also support the outcome hypothesis of La Porta et al. (2000), which states that dividends can be considered as substitutes as well as outcomes of governance mechanisms. In this case, dividends in family firms might be seen as an outcome of non-family involvement in governance systems.

Previous family business research concluded that professionalization leads to better financial lending terms (Barden et al., 1984) and a higher likelihood of obtaining private equity funding (Dawson, 2011). Our study adds another financial argument for professionalization to this list, which is especially interesting for passive shareholders in family firms: professionalization appears to increase the likelihood that excess cash will be distributed on a pro rata basis to all shareholders (i.e. via dividend payouts), thereby reducing possible agency costs related to altruism, self-control or nepotism.

\subsection{Limitations and suggestions for future research}

This study has several limitations which could provide avenues for future research. First, using longitudinal data on the level of professionalization will allow us to investigate the impact of changes in professionalization on dividend payout over time, which might provide additional 
interesting insights. Second, the sample consists only of Belgian privately held family firms. Even though this might seem like a limitation, the sample has the advantage of providing objective financial data for privately held family firms via the Bel-First database (Bureau Van Dijk), which is uncommon in most countries. Third, data from a larger sample of family firms, or from a different country, could be used to test the generalizability of our results. Fourth, although intercorrelations between the different dimensions of professionalization are very low, future research might examine possible moderator effects among these variables. Finally, the results indicate that the level of professionalization impacts dividend policy. This result could inspire many future research directions, for example, investigating the impact of professionalization on different financial decisions, such as capital structure. These new research topics derived from this study could be of interest to both family business and corporate finance scholars.

\subsection{Theoretical and practical implications}

This study makes a number of valuable contributions to the academic literature. First, while professionalization research emanates mainly from management studies, and dividend research from corporate finance, we integrate insights from both disciplines. This could significantly advance family business and finance research. Second, while prior work has mainly focused on the difference between family and non-family firms or public and private firms, we investigate the impact of professionalization on dividend payout within the group of privately held family firms. Third, by adopting a broader family business professionalization perspective, we contribute to the family business literature as our reasoning goes beyond the effect of family involvement on dividend payout alone, as was investigated by González et al. (2014). As a successful application of a more extended operationalization of professionalization, this scale could also be used to explore professionalization in other SME contexts. Finally, the results of this study may also be of interest to family business practitioners or consultants, as they show that different modes of professionalization in family firms influence the level of dividend payout.

\section{CONCLUSION}

This paper contributes to the ongoing debate about dividend payments in family-controlled firms. These firms are assumed to follow financial logic that is driven by both economic and non-economic motives (Gallo et al., 2004; Koropp et al., 2014), and several studies have already investigated the influence of family ownership and/or management on dividend policies 
(e.g. Chen et al., 2005; Farinha, 2003; Gugler, 2003; Pindado et al., 2011; Setia-Atmaja et al., 2009; Yoshikawa and Rasheed, 2010). Recently, the subgroup of privately held family firms has also attracted attention from several researchers (González et al., 2014; Michiels et al. 2015; Vandemaele and Vancauteren, 2015). Although these studies have started to open the black box of dividend payments in privately held family firms by investigating the influence of family governance practices (Michiels et al., 2015) and family influence in ownership and management (González et al., 2014; Vandemaele and Vancauteren, 2015) on a firm's dividend policy, there is still much work to do before we thoroughly understand why, when and how private family firms pay dividends. We contribute to this debate by exploring in more detail the relationship between family firm professionalization and dividend payout. Our results indicate that three out of five dimensions of professionalization, including the use of financial and human resource control systems, and high levels of non-family involvement in governance, significantly and positively influence the dividend payout ratio. According to these results, the level to which a family firm has professionalized in these aspects significantly influences the dividend payout, suggesting that professionalization seems to reduce agency costs related to parental altruism or nepotism. Our study therefore adds an important variable to the dividend literature alongside the traditional determinants (firm size, firm age, leverage, profitability, liquidity, growth) and clearly indicates the need to take into account the heterogeneity of private family firms to explain why, how and when family firms pay out dividends. 


\section{REFERENCES}

Anderson, R. C., and Reeb, D. M. (2004), "Board composition: Balancing family influence in S\&P 500 firms", Administrative Science Quarterly, Vol. 49 No. 2, pp. 209-237.

Baker, H. K. (1989), "Why companies pay no dividends", Akron Business and Economic Review, Vol. 20 No. 2, pp. 48-61.

Barden, R. S., Copeland Jr, J. E., Hermanson, R. H. and Wat, L. (1984), "Going public--what it involves: A framework for providing advice to management", Journal of Accountancy (pre-1986), Vol. 157 No. 3, pp. 63.

Berenbeim, R. E. (1990), "How business families manage the transition from owner to professional management", Family Business Review, Vol. 3 No. 1, pp. 69-110.

Blanco-Mazagatos, V., Quevedo-Puente, D. and Castrillo, L. A. (2007), "The trade-off between financial resources and agency costs in the family business: An exploratory study", Family Business Review, Vol. 20 No. 3, pp. 199-213.

Bloom, N. and Van Reenen, J. (2007), "Measuring and explaining management practices across firms and countries", Quarterly Journal of Economics, Vol. 122 No. 4, pp. 1351-1408.

Carney, M. (2005), "Corporate governance and competitive advantage in family-controlled firms", Entrepreneurship Theory and Practice, Vol. 29 No. 3, pp. 249-265.

Carney, M. and Gedajlovic, E. (2002), "The coupling of ownership and control and the allocation of financial resources: Evidence from Hong Kong", Journal of Management Studies, Vol. 39 No. 1, pp. 123-146.

Carney, M., Van Essen, M., Gedajlovic, E. R. and Heugens, P. P. (2013), "What do we know about private family firms? A meta-analytical review", Entrepreneurship Theory and Practice, Vol. 39 No. 3, pp. 513-544.

Chen, Z., Cheung, Y. L., Stouraitis, A. and Wong, A. W. (2005), "Ownership concentration, firm performance, and dividend policy in Hong Kong", Pacific-Basin Finance Journal, Vol. 13 No. 4, pp. 431-449.

Chrisman, J. J., Chua, J. H. and Litz, R. A. (2004), Comparing the agency costs of family and non-family firms: Conceptual issues and exploratory evidence", Entrepreneurship Theory and Practice, Vol. 28 No. 4, pp. 335-354.

Chua, J. H., Chrisman, J. J. and Bergiel, E. B. (2009), "An agency theoretic analysis of the professionalized family firm", Entrepreneurship Theory and Practice, Vol. 33 No. 1, pp. 355-372. 
Chua, J. H., Chrisman, J. J. and Sharma, P. (1999), "Defining the family business by behavior", Entrepreneurship Theory and Practice, Vol. 23 No.1, pp. 19-40.

Chua, J. H., Chrisman, J. J., Steier, L. P. and Rau, S. B. (2012), "Sources of heterogeneity in family firms: An introduction", Entrepreneurship Theory and Practice, Vol. 36 No. 6, pp. 1103-1113.

Daily, C. M. and Dollinger, M. J. (1992), "An empirical examination of ownership structure in family and professionally managed firms", Family Business Review, Vol. 5 No. 2, pp. 117-136.

Dawson, A. (2011), "Private equity investment decisions in family firms: The role of human resources and agency costs", Journal of Business Venturing, Vol. 26 No. 2, pp. 189199.

DeAngelo, H. and DeAngelo, L. (2000), "Controlling stockholders and the disciplinary role of corporate payout policy: A study of the Times Mirror Company", Journal of Financial Economics, Vol. 56 No. 2, pp. 153-207.

DeAngelo, H., DeAngelo, L. and Stulz, R. M. (2004), "Dividend policy, agency costs, and earned equity", working paper, National Bureau of Economic Research, Cambridge: MA.

DeAngelo, H., DeAngelo, L. and Stulz, R. M. (2006), "Dividend policy and the earned/contributed capital mix: A test of the life-cycle theory", Journal of Financial Economics, Vol. 81 No. 2, pp. 227-254.

Dekker, J. C., Lybaert, N., Steijvers, T., Depaire, B. and Mercken, R. (2013), "Family firm types based on the professionalization construct: Exploratory research", Family Business Review, Vol. 26 No. 1, pp. 81-99.

Dekker, J., Lybaert, N., Steijvers, T. and Depaire, B. (2015), "The effect of family business professionalization as a multidimensional construct on firm performance", Journal of Small Business Management, Vol. 53 No. 2, pp. 516-538.

De Kok, J. M. P. and Uhlaner, L. M. (2001), "Organizational context and human resource management in the small firm", Small Business Economics, Vol. 17 No. 4, pp. 273-291.

De Kok, J. M. P., Uhlaner, L. M. and Thurik, A. R. (2006), "Professional HRM practices in family owned-managed enterprises", Journal of Small Business Management, Vol. 44 No. 3, pp. 441-460.

Denis, D. J. and Osobov, I. (2008), "Why do firms pay dividends? International evidence on the determinants of dividend policy", Journal of Financial Economics, Vol. 89 No. 1, pp. 62-82. 
Dyer, W. G. (1989), "Integrating professional management into a family owned business", Family Business Review, Vol. 2 No. 3, pp. 221-235.

Dyer, W. G. (2006), "Examining the 'family effect' on firm performance", Family Business Review, Vol. 19 No. 4, pp. 253-273.

Easterbrook, F. H. (1984), "Two agency-cost explanations of dividends", American Economic Review, Vol. 3 No. 1, pp. 650-659.

Fama, E. F. and French, K. R. (2001), "Disappearing dividends: Changing firm characteristics or lower propensity to pay?", Journal of Financial Economics, Vol. 60 No. 1, pp. 3-43.

Farinha, J. (2003), "Dividend policy, corporate governance and the managerial entrenchment hypothesis: An empirical analysis", Journal of Business Finance \& Accounting, Vol. 30 No. 10, pp. 1173-1209.

Fenn, G. W. and Liang, N. (2001), "Corporate payout policy and managerial stock incentives", Journal of Financial Economics, Vol. 60 No. 1, pp. 45-72.

Filatotchev, I., Lien, Y. C. and Piesse, J. (2005), "Corporate governance and performance in publicly listed, family-controlled firms: Evidence from Taiwan", Asia Pacific Journal of Management, Vol. 22 No. 3, pp. 257-283.

Flamholtz, E. and Randle, Y. (2007), Growing pains: Transitioning from an entrepreneurship to a professionally managed firm, Jossey-Bass, San Francisco.

Fletcher, D. (2002), "A network perspective of cultural organising and 'professional management' in the small, family business", Journal of Small Business and Enterprise Development, Vol. 9 No. 4, pp. 400-415.

Gabrielsson, J. (2007), "Correlates of board empowerment in small companies", Entrepreneurship Theory and Practice, Vol. 31 No. 5, pp. 687-711.

Gallo, M. Á., Tàpies, J. and Cappuyns, K. (2004), "Comparison of family and nonfamily business: Financial logic and personal preferences", Family Business Review, Vol. 17 No. 4, pp. 303-318.

García Pérez de Lema, D. and Duréndez, A. (2007), "Managerial behaviour of small and medium-sized family businesses: An empirical study", International Journal of Entrepreneurial Behavior \& Research, Vol. 13 No. 3, pp. 151-172.

Gedajlovic, E., Lubatkin, M. H. and Schulze, W. S. (2004), "Crossing the threshold from founder management to professional management: A governance perspective", Journal of Management Studies, Vol. 41 No. 5, pp. 899-912. 
Gersick, K. E., Davis, J. A., Hampton, M. M. and Lansberg, I. (1997), Generation to generation: Life cycles of family business. Harvard Business School Press Books, Boston.

Giovannoni, E., Maraghini, M. P. and Riccaboni, A. (2011), "Transmitting knowledge across generations: The role of management accounting practices", Family Business Review, Vol. 24 No. 2, pp. 126-150.

Gómez-Mejía, L. R., Haynes, K. T., Núñez-Nickel, M., Jacobson, K. J. L. and Moyano-Fuentes, J. (2007), "Socioemotional wealth and business risks in family-controlled firms: Evidence from spanish olive oil mills", Administrative Science Quarterly, Vol. 52 No. 1, pp. 106-137.

González, M., Guzmán, A., Pombo, C. and Trujillo, M. A. (2014), "Family involvement and dividend policy in closely held firms", Family Business Review, Vol. 27 No. 4, pp. 365385.

García Pérez de Lema, D. and Duréndez, A. (2007), "Managerial behaviour of small and medium-sized family businesses: An empirical study", International Journal of Entrepreneurial Behavior \& Research, Vol. 13 No. 3, pp. 151-172.

Gugler, K. (2003), "Corporate governance, dividend payout policy, and the interrelation between dividends, R\&D, and capital investment", Journal of Banking \& Finance, Vol. 27 No. 7, pp. 1297-1321.

Gujarati, D. (2003), Basic Econometrics (4 ed.),McGraw Hill, Boston.

Gulbrandsen, T. (2005), "Flexibility in Norwegian family-owned enterprises", Family Business Review, Vol. 18 No. 1, pp. 57-76.

Hair Jr, J. F. (2006). Black, WC, Babin, BJ Anderson, RE \& Tatham, RL (2006). Multivariate data analysis, $6^{\text {th }}$ edition.

Hall, A. and Nordqvist, M. (2008), "Professional management in family businesses: Toward an extended understanding", Family Business Review, Vol. 21 No. 1, pp. 51-69.

$\mathrm{Hu}$, A. and Kumar, P. (2004), "Managerial entrenchment and payout policy", Journal of Financial and Quantitative Analysis, Vol. 39 No. 4, pp. 759-790.

Huang, Y., Chen, A. and Kao, L. (2012), "Corporate governance in Taiwan: The nonmonotonic relationship between family ownership and dividend policy", Asia Pacific Journal of Management, Vol. 29 No. 1, pp. 39-58.

Jensen, M. C. (1986), "Agency costs of free cash flow, corporate finance, and takeovers", American Economic Review, Vol. 76 No. 2, pp. 323-329. 
Jensen, M. C. and Meckling, W. H. (1976), "Theory of the firm: Managerial behavior, agency costs and ownership structure", Journal of Financial Economics, Vol. 3 No. 4, pp. 305360 .

Kanuk, L. and Berenson, C. (1975), "Mail surveys and response rates: A literature review", Journal of Marketing Research, Vol. 12 No. 4, pp. 440-453.

Kellermanns, F. W. and Eddleston, K. A. (2004), "Feuding families: When conflict does a family firm good", Entrepreneurship Theory and Practice, Vol. 28 No. 3, pp. 209-228.

Kline, P. (2013), Handbook of psychological testing, Routledge, London.

Koropp, C., Kellermanns, F. W., Grichnik, D. and Stanley, L. (2014), "Financial decision making in family firms: An adaptation of the theory of planned behavior", Family Business Review, Vol. 27 No. 4, pp. 307-327.

Kopriva, I. and Bernik, M. (2009), "Comparison of human resource management in Slovenian family and non-family businesses", Organizacija, Vol. 42 No. 6, pp. 246-254.

Kotey, B. and Folker, C. (2007), "Employee training in SMEs: Effect of size and firm typeFamily and nonfamily", Journal of Small Business Management, Vol. 45 No. 2, pp. 214238 .

Lane, S., Astrachan, J., Keyt, A. and McMillan, K. (2006), "Guidelines for family business boards of directors", Family Business Review, Vol. 19 No. 2, pp. 147-167.

La Porta, R., Lopez-de-Silanes, F., Shleifer, A. and Vishny, R. W. (2000), "Agency problems and dividend policies around the world", Journal of Finance, Vol. 55 No. 1, pp. 1-33.

Lee, K. (2010), "Retail minority shareholders and corporate reputation as determinat of dividend policy in Australia", Pacific-Basin Finance Journal, Vol. 18 No. 1, pp. 351368 .

Lipson, M. , Maquieria, C. and Megginson, W. (1998), "Dividend initations and earnings suprises", Financial Management, Vol. 27 No. 3, pp. 27-45.

Lubatkin, M. H., Schulze, W. S., Ling, Y. and Dino, R. N. (2005), "The effects of parental altruism on the governance of family-managed firms", Journal of Organizational Behavior, Vol. 26 No. 3, pp. 313-328.

Mahérault, L. (2000), "The influence of going public on investment policy: An empirical study of French family-owned businesses", Family Business Review, Vol. 13(1), pp. 71-79.

McDonald, J. F. and Moffitt, R. A. (1980), "The uses of Tobit analysis", Review of economics and statistics, Vol. 62 No. 2, pp. 318-321.

Michiels, A. (2017), "Formal compensation practices in family SMEs", Journal of Small Business and Enterprise Development, Vol. 24 No. 1, pp. 88-104. 
Michiels, A., Voordeckers, W., Lybaert, N. and Steijvers, T. (2015), "Dividends and family governance practices in private family firms", Small Business Economics, Vol. 44 No. 2, pp. 299-314.

Michiels, A., Voordeckers, W., Lybaert, N. and Steijvers, T. (2013), "CEO compensation in private family firms pay-for-performance and the moderating role of ownership and management", Family Business Review, Vol. 26 No. 2, pp. 140-160.

Naceur, S. B., Goaied, M. and Belanes, A. (2006), "On the determinants and dynamics of dividend policy", International Review of Finance, Vol. 6 No. 1-2, pp. 1-23.

Nordqvist, M., Sharma, P. and Chirico, F. (2014), "Family firm heterogeneity and governance: A configuration approach" Journal of Small Business Management, Vol. 52 No. 2, pp. 192-209.

Oppenheim, A. N. (2000), Questionnaire design, interviewing and attitute management, Continuum Intl Pub Group.

Pieper, T. M., Klein, S. B. and Jaskiewicz, P. (2008), "The impact of goal alignment on board existence and top management team composition: Evidence from family-influenced businesses", Journal of Small Business Management, Vol. 46 No. 3, pp. 372-394.

Pindado, J., Requejo, I. and de la Torre, C. (2011), "Family control and investment-cash flow sensitivity: Empirical evidence from the Euro zone", Journal of Corporate Finance, Vol. 17 No. 5, pp. 1389-1409.

Porter, M. E. (1980), "Competitive strategy: Techniques for analyzing industries and competition", The Free Press, New York.

Poutziouris, P. (2001), "The views of family companies on venture capital: Empirical evidence from the UK small to medium-size enterprising economy", Family Business Review, Vol. 14 No. 3, pp. 277-291.

Reid, R., Morrow, T., Kelly, B. and McCartan, P. (2002), "People management in SMEs: An analysis of human resource strategies in family and non-family businesses" Journal of Small Business and Enterprise Development, Vol. 9 No. 3, pp. 245-259.

Renneboog, L. and Trojanowski, G. (2007), "Control structures and payout policy", Managerial Finance, Vol. 33 No. 1, pp. 43-64.

Romano, C. A., Tanewski, G. A., and Smynrios, K. X. (2000), "Capital structure decision making: A model for family business", Journal of Business Venturing, Vol. 16 No. 3, pp. 285-310. 
Rommens, A., Cuyvers, L. and Deloof, M. (2012), "Dividend policies of privately held companies: Stand-alone and group companies in Belgium", European Financial Management, Vol. 18 No. 5, pp. 816-835.

Rozeff, M. S. (1982), "Growth, beta and agency costs as determinants of dividend payout ratios", Journal of financial Research, Vol. 5 No. 3, pp. 249-259.

Samuelsson, J., Andersén, J., Ljungkvist, T. and Jansson, C. (2016), "Formal accounting planning in SMEs: The influence of family ownership and entrepreneurial orientation", Journal of Small Business and Enterprise Development, Vol. 23 No. 3, pp. 691-702.

Schulze, W. S., Lubatkin, M. H., Dino, R. N. and Buchholtz, A. K. (2001), "Agency relationships in family firms: Theory and evidence", Organization Science, Vol. 12 No. 2, pp. 99-116.

Schulze, W. S., Lubatkin, M. H. and Dino, R. N. (2003), "Toward a theory of agency and altruism in family firms", Journal of Business Venturing, Vol. 18 No. 4, pp. 473-490.

Sciascia, S. and Mazzola, P. (2008), "Family involvement in ownership and management: Exploring nonlinear effects on performance", Family Business Review, Vol. 21 No. 4, pp. 331-345.

Setia-Atmaja, L. (2010), "Dividend and debt policies of family controlled firms: The impact of board independence", International Journal of Managerial Finance, Vol. 6 No. 2, pp. 128-142.

Setia-Atmaja, L., Tanewski, G. A. and Skully, M. (2009), "The role of dividends, debt and board structure in the governance of family controlled firms", Journal of Business Finance \& Accounting, Vol. 36 No. 7/8, pp. 863-898.

Sharma, V. (2011), "Independent directors and the propensity to pay dividends", Journal of Corporate Finance, Vol. 17 No. 4, pp. 1001-1015.

Songini, L. (2006), "The professionalization of family firms: Theory and practice", in Poutziouris, P. Z., Smyrnios, K. X. \& Klein, S. B. (Eds), Handbook of research on family business, Edward Elgar, Cheltenham, pp. 269-297.

Stewart, A. and Hitt, M. A. (2012), "Why can't a family business be more like a nonfamily business? Modes of professionalization in family firms", Family Business Review, Vol. 25 No. $1,58-86$.

Tobin, J. (1958), "Estimation of relationships for limited dependent variables", Econometrica: Journal of the Econometric Society, pp. 24-36. 
Vandemaele, S. and Vancauteren, M. (2015), "Nonfinancial goals, governance, and dividend payout in private family firms", Journal of Small Business Management, Vol. 53 No. 1, pp. 166-182.

Ward, J. L. (1997), "Growing the family business: Special challenges and best practices", Family Business Review, Vol. 10 No. 4, pp. 323-337.

Westhead, P. and Howorth, C. (2007), "Types' of private family firms: An exploratory conceptual and empirical analysis", Entrepreneurship and Regional Development, Vol. 19 No. 5, pp. 405-431.

Whisler, T. L. (1988), "The role of the board in the threshold firm", Family Business Review, Vol. 1 No. 3, pp. 309-321.

Wooldridge, J. M. (2010), Econometric analysis of cross section and panel data, MIT press, Cambridge: MA.

Wu, Z., Chua, J. H. and Chrisman, J. J. (2007), "Effects of family ownership and management on small business equity financing", Journal of Business Venturing, Vol. 22 No. 6, pp. 875-895.

Yildirim-Öktem, Ö. and Üsdiken, B. (2010), "Contingencies versus external pressure: Professionalization in boards of firms affiliated to family business groups in lateindustrializing countries", British Journal of Management, Vol. 21 No. 1, pp. 115-130.

Yoshikawa, T. and Rasheed, A. A. (2010), "Family control and ownership monitoring in family-controlled firms in Japan", Journal of Management Studies, Vol. 47 No. 2, pp. 274-295. 
Figure 1. Research Design

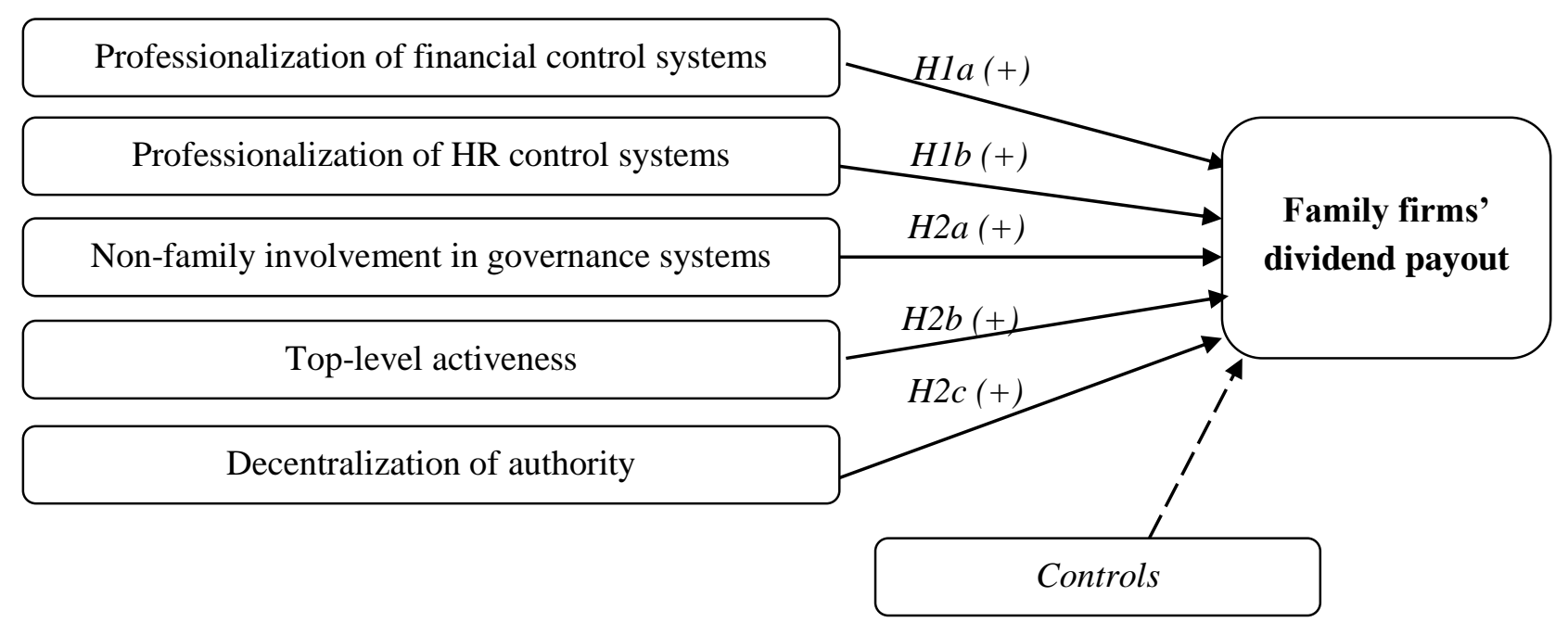




\section{Table 1}

\section{Descriptions of the Variables}

Dividend payout

Financial Control Systems ${ }^{a}$

Human Resource Control

Systems a

Non-family Involvement

in Governance Systems ${ }^{\text {a }}$

Top-Level Activeness ${ }^{\text {a }}$

Decentralization of Authority ${ }^{\mathrm{a}}$

Firm Age

Firm Size

Profitability

Leverage

Liquidity

Growth

Generation

Number of owners

Sector controls
The amount of dividend payout divided by total assets, averaged over thre 2012)

$\mathrm{P} 1$, includes items on the use of financial control systems in family firms.

P2, includes items on the use of human resource control systems in family firı

$\mathrm{P} 3$, includes items on non-family involvement in the governance systems of family firms.

$\mathrm{P} 4$, includes items on the top-level activeness in family firms.

P5, includes items on the decentralization of authority in family firms.

Firm age in 2010

Total assets, averaged over three years (2010-2012)

Return on assets, calculated by income before interest, tax, depreciation anc divided by total assets. Averaged over three years (2010-2012)

Long-term debt divided by total assets, averaged over three years (2010-2012

Short-term assets (cash, inventory, receivables) divided by short-term liabilities (debt and payables), averaged over three years (2010-2012) Growth rate of assets in $2011\left(\mathrm{dA}_{\mathrm{t}} / \mathrm{A}_{\mathrm{t}}\right)$

Dummy variable, equals one for first-generation family firms, zero otherwise (later-generation family firms)

Number of shareholders in 2010

Four dummy variables (wholesale, services, construction and industry)

Notes $^{\text {a }}$ see Appendix for more detailed descriptions of the items 
Table 2

Descriptive statistics and correlations for all variables

\begin{tabular}{|c|c|c|c|c|c|c|c|c|c|c|c|c|c|c|c|}
\hline Variables & Mean & S.D. & 1 & 2 & 3 & 4 & 5 & 6 & 7 & 8 & 9 & 10 & 11 & 12 & 13 \\
\hline 1. Dividend payout & .02 & .04 & 1.00 & & & & & & & & & & & & \\
\hline 2. Financial Control Systems & & & .02 & 1.00 & & & & & & & & & & & \\
\hline 3. Human Resource Control Systems & & & $.14^{* *}$ & .00 & 1.00 & & & & & & & & & & \\
\hline $\begin{array}{l}\text { 4. Non-family Involvement in Governance } \\
\text { Systems }\end{array}$ & & & $.19^{* *}$ & .00 & .01 & 1.00 & & & & & & & & & \\
\hline 5. Top-Level Activeness & & & -.07 & .00 & -.01 & -.03 & 1.00 & & & & & & & & \\
\hline 6. Decentralization of Authority & & & .07 & .00 & .01 & .01 & .01 & 1.00 & & & & & & & \\
\hline 7. Firm Age (ln) & 3.16 & .49 & .01 & -.04 & -.02 & -.06 & .02 & .03 & 1.00 & & & & & & \\
\hline 8. Firm Size (ln) & 3.09 & .67 & .05 & $.11^{*}$ & $.13^{* *}$ & $.21^{* *}$ & $.25^{* *}$ & .04 & $.14^{* *}$ & 1.00 & & & & & \\
\hline 9. Profitability (avg) & 4.02 & 9.19 & $.50^{* *}$ & $-.08^{*}$ & $.13^{*}$ & $.08^{\dagger}$ & $.07^{\dagger}$ & -.02 & $-.09^{\dagger}$ & $.09^{*}$ & 1.00 & & & & \\
\hline 10. Leverage (avg) & .15 & .15 & $-.20^{* * *}$ & $-.07^{*}$ & -.07 & -.03 & -.05 & $.10^{*}$ & $-.15^{* *}$ & -.05 & $-.21^{* * *}$ & 1.00 & & & \\
\hline 11. Liquidity (avg) & 1.87 & 2.06 & .05 & $-.08 *$ & -.01 & -.06 & .01 & -.05 & $.15^{* *}$ & -.07 & $.12^{*}$ & $-.16^{* *}$ & 1.00 & & \\
\hline 12. Growth & .10 & .43 & -.06 & -.06 & -.00 & -.04 & -.04 & .06 & -.07 & .02 & $.30^{* *}$ & $.11^{*}$ & -.05 & 1.00 & \\
\hline 13. Generation & .39 & .49 & .06 & -.01 & .06 & $.15^{* *}$ & -.02 & -.06 & $-.34^{* *}$ & $-.11^{*}$ & .06 & .04 & $-.10^{*}$ & .05 & \\
\hline 14. Owners & 2.26 & 1.58 & -.01 & -.01 & -.01 & .04 & $.20^{* *}$ & $.08^{\dagger}$ & .06 & $.11^{*}$ & -.02 & $-.07^{\dagger}$ & .01 & -.06 & $-.14^{* *}$ \\
\hline
\end{tabular}

Notes. $N=492 ; \dagger p<.10, * \mathrm{p}<.05, * * \mathrm{p}<.01$; two-tailed test 
Table 3

Tobit regression models

\begin{tabular}{|c|c|c|c|c|c|}
\hline & \multirow[b]{2}{*}{$\boldsymbol{H}$} & \multicolumn{3}{|c|}{ Robust } & \multirow{2}{*}{$\begin{array}{l}\text { Robust } \\
\text { Std. Error }\end{array}$} \\
\hline & & Model 1 & $\begin{array}{l}\text { Std. } \\
\text { Error }\end{array}$ & Model 2 & \\
\hline Constant & & $-.1391 * *$ & .0368 & $-.1243 * *$ & .0357 \\
\hline \multicolumn{6}{|l|}{ FAMILY FIRM PROFESSIONALIZATION } \\
\hline P1 - Financial Control Systems & $H 1 a$ & & & $.0074^{\dagger}$ & .0042 \\
\hline P2 - Human Resource Control Systems & $H 1 b$ & & & $.0087 *$ & .0039 \\
\hline P3 - Nonfamily Involvement in Governance Systems & $H 2 a$ & & & $.0079 *$ & .0038 \\
\hline P4 - Top Level Activeness & $H 2 b$ & & & .0003 & .0043 \\
\hline P5 - Decentralization of Authority & $H 2 c$ & & & .0048 & .0051 \\
\hline \multicolumn{6}{|l|}{ CONTROLS } \\
\hline Firm Age ${ }^{a}$ & & .0129 & .0087 & $.0154^{\dagger}$ & .0084 \\
\hline Firm Size ${ }^{a}$ & & .0108 & .0066 & .0039 & .0066 \\
\hline Profitability & & $.0060 * *$ & .0006 & $.0058 * *$ & .0006 \\
\hline Leverage & & $.0732 *$ & .0352 & $-.068 *$ & .0335 \\
\hline Liquidity & & .0002 & .0018 & .0006 & .0017 \\
\hline Growth & & $-.0674 * *$ & .0228 & $-.060 * *$ & .0212 \\
\hline Generation & & .0102 & .0095 & .0069 & .0095 \\
\hline Number of owners & & .0019 & .0019 & .0017 & .0020 \\
\hline Sector controls ${ }^{b}$ & & Yes & & Yes & \\
\hline LR Chi-Square & & $178.00 * *$ & & $188.20 * *$ & \\
\hline$N$ & & 492 & & 492 & \\
\hline
\end{tabular}

Notes. $N=492 ;{ }^{\dagger} p<.10,{ }^{*} \mathrm{p}<.05,{ }^{*} * \mathrm{p}<.01 ;$ two-tailed test; ${ }^{a}$ natural logarithm, ${ }^{\mathrm{b}}$ wholesale was used as a reference category 
Table 4

Robustness check: Tobit regression models without single-owner firms

\begin{tabular}{|c|c|c|c|c|}
\hline & Model 1 & $\begin{array}{l}\text { Robust } \\
\text { Std. Error }\end{array}$ & Model 2 & $\begin{array}{l}\text { Robust } \\
\text { Std. Error }\end{array}$ \\
\hline Constant & $-.1172 *$ & .0482 & $-.0965 *$ & .04478 \\
\hline \multicolumn{5}{|l|}{ FAMILY FIRM PROFESSIONALIZATION } \\
\hline P1 - Financial Control Systems & & & $.00866^{\dagger}$ & .0050 \\
\hline P2 - Human Resource Control Systems & & & $.0115^{*}$ & .0048 \\
\hline $\begin{array}{l}\text { P3 - Non-family Involvement in Governance } \\
\text { Systems }\end{array}$ & & & $.0121 *$ & .0052 \\
\hline P4 - Top-Level Activeness & & & .0027 & .0051 \\
\hline P5 - Decentralization of Authority & & & .0048 & .0051 \\
\hline \multicolumn{5}{|l|}{ CONTROLS } \\
\hline Firm Age ${ }^{a}$ & .0067 & .0110 & .0115 & .0102 \\
\hline Firm Size ${ }^{a}$ & .0098 & .0085 & -.0001 & .0085 \\
\hline Profitability & $.0048 * *$ & .0007 & $.0046 * *$ & .0007 \\
\hline Leverage & -.062 & .047 & -.0584 & .0390 \\
\hline Liquidity & $.0082^{\dagger}$ & .0043 & $.0072^{\dagger}$ & .0041 \\
\hline Growth & $-.0800 *$ & .0032 & $-.0680 *$ & .0296 \\
\hline Generation & .0026 & .0121 & -.0017 & .0122 \\
\hline Sector controls & Yes & & Yes & \\
\hline LR Chi-Square & $92.85 * *$ & & $104.04 * *$ & \\
\hline$N$ & 325 & & 325 & \\
\hline
\end{tabular}

Notes. $N=325 ;{ }^{\dagger} p<.10,{ }^{*} \mathrm{p}<.05, * * \mathrm{p}<.01$; two-tailed test; ${ }^{a}$ natural logarithm 


\section{APPENDIX - Professionalization measures ${ }^{3}$}

Factor loadings for varimax rotated five-factor model

\begin{tabular}{|c|c|c|c|}
\hline Dimension & $\begin{array}{l}\text { Chronbach's } \\
\text { alpha }\end{array}$ & Item & Factor loading \\
\hline \multirow[t]{4}{*}{ P1 - Financial Control Systems } & \multirow[t]{4}{*}{.78} & Use of budgets & .870 \\
\hline & & Budget evaluation system & .842 \\
\hline & & Formalized financial goals and objectives & .642 \\
\hline & & Firm performance evaluation system & .553 \\
\hline \multirow{4}{*}{$\begin{array}{l}\text { P2 - Non-family Involvement in } \\
\text { Governance Systems }\end{array}$} & \multirow[t]{4}{*}{.65} & Family involvement in board of directors $(\mathrm{R})^{\mathrm{a}}$ & .816 \\
\hline & & External board members & .738 \\
\hline & & Family involvement in management team (R) & .625 \\
\hline & & Non-family CEO & .623 \\
\hline \multirow[t]{5}{*}{ P3 - Human Resource Control Systems } & \multirow[t]{5}{*}{.62} & Formal recruitment system & .655 \\
\hline & & Formal training system & .622 \\
\hline & & Incentive payment system & .532 \\
\hline & & Personnel performance evaluation system & .503 \\
\hline & & Formal scheduled staff meetings a & .459 \\
\hline \multirow{2}{*}{ P4 - Top-Level Activeness } & \multirow[t]{2}{*}{.55} & Board activeness & .829 \\
\hline & & Management Activeness & .637 \\
\hline \multirow[t]{3}{*}{ P5 - Decentralizaton of Authority } & \multirow[t]{3}{*}{.57} & Delegation of control & .813 \\
\hline & & Centralized individual decision-making $(\mathrm{R})$ & .681 \\
\hline & & Centralization of authority (R) & .584 \\
\hline .805 & KMO Index & & \\
\hline .000 & Bartlett's sigr & nce test of sphericity & \\
\hline
\end{tabular}

Notes. (R) indicates that the item was reverse coded; ${ }^{\mathrm{a}}$ measured as percentage of family directors to total number of directors in the board; ${ }^{b}$ measured as a percentage of family managers to total number of managers in the management team;

\footnotetext{
${ }^{3}$ For a more detailed description of the factors, see Dekker et al. (2013).
} 


\section{Survey questions for the five dimensions of professionalization}

\section{Factor 1 - Financial Control Systems}

- Is there a report or document in which the company objectives with reference to next year's sales are fully and accurately computed? $0=$ no; $1=$ yes (assessing formalized financial goals and objectives)

- Does the company own reports in which the proposed budgets of the company are compared with the actual figures? $0=$ no; $1=$ yes (assessing use of budgets)

- Are the deviations from the budgeted targets monitored to perhaps undertake future actions? $0=$ no; $1=$ yes (assessing use of budget evaluation system)

- Does management prepare quarterly reports? $0=$ no; $1=y e s$ (assessing use of firm performance evaluation system)

\section{Factor 2 - Human Resource Control Systems}

- $\quad$ Are the staff meetings usually formally prepared and planned in advance? $0=$ no; $1=y e s$ (assessing formal scheduled staff meetings)

- Does the company use incentive payments based on performance, for example through bonuses? $0=$ no; $1=\mathrm{yes}$ (assessing use of incentive payment system)

- Are the periodical performance reviews with the managers of the company drawn up in reports? $0=$ no; $1=y e s$ (assessing use of personnel performance evaluation system)

- Are the procedures regarding the recruitment of new staff noted down in a document? $0=$ no; $1=$ yes (assessing use of formal recruitment system)

- Does the company provide formal internal or external training programs for their employees? $0=n o$; $1=y e s$ (assessing use of formal training system)

\section{Factor 3 - Non-family Involvement in Governance Systems}

- $\quad$ Are you, as CEO, part of the family? 0=yes; $1=$ no (assessing nature of CEO)

- How many managers are part of the management team (including CEO)?

- How many managers of this management team are connected by blood bonds? (assessing non-family involvement in management - reverse coded)

- How many board directors are connected by blood bonds? (assessing non-family involvement in board - reverse coded)

- How many people (= natural individuals) are part of the board of directors?

- How many external people (= non-relatives and not working for the company) are there on this board of directors? (assessing involvement of external, independent members in board)

\section{Factor 4 - Top-Level Activeness}

- How often does the management team officially meet on an annual basis? (assessing management activeness)

- How often does the board of directors officially meet on an annual basis? (assessing board activeness)

\section{Factor 5 - Decentralization of Authority}

- Does the CEO of the company individually decide which organizational strategy must be followed? $0=$ yes; $1=$ no

(assessing centralized decision-making)

- Do all employees within the company directly report to the CEO (without using an intermediary)? $0=y e s ;$ $1=$ no (assessing centralization of authority)

- Are all major decisions within the company autonomously made by the CEO, and then communicated downwards? $0=\mathrm{yes} ; 1=\mathrm{no}$ (assessing possible delegation of control) 